Natalia Wasilewska

Jan Kochanowski University in Kielce

Tetiana Kaminska

Kyiv Cooperative Institute of Business and Law

\title{
PRECONDITIONS OF LAND RELATIONS DEVELOPMENT: ECONOMIC, LEGAL AND INSTITUTIONAL
}

This paper discusses the issues related to the implementation of the land reform in Ukraine. The purpose of the research is to work out a system of measures aimed at developing land relations, in particular, the introduction of the land market in Ukraine, as well as determining the economic impact of the effective turnover of land plots. The analysis of the economic situation in Ukraine over the past 10 years has been carried out. Issues related to land legislation, in particular land valuation, are briefly identified. The institutions without functioning of which the introduction of the land market is impossible, are established. The conducted analysis gave basis to the proposal of preconditions of economic, legal and institutional character, necessary for the successful development of land relations. The article also proposes mortgage refinancing mechanism through the issue of mortgage land securities.

Key words: economic, legal and institutional preconditions, land market, land evaluation, mortgage institution, moratorium on sale of agricultural land.

\section{Introduction}

Since 2008 the Ukrainian economy has felt the first and painful consequences of the global financial crisis. Ukraine was and is an import-oriented country. In 2007 Ukrainian commercial banks gave about $70 \%$ of credits in foreign currency. During short period the Ukrainian hryvnia had significantly lost its value. Thus, in the beginning of 2008 exchange rate of Hryvnia to US dollar was about 5:1, in $2009-8: 1$ ! It became a real challenge for Ukraine. Borrowers weren't be able to fulfill their financial obligations. Banks began to lose their liquidity, business began to decline, real estate markets were in a state of stagnation. All sectors of the Ukrainian economy were covered by the crisis. But in 2010 the difficult situation was changed. A lot of enterprises, banks and other institutions were adapted to the new environment.

Table 1. Dynamics of GDP of Ukraine during 2008-2017

\begin{tabular}{|c|c|c|c|c|}
\hline \multirow[t]{2}{*}{ Year } & \multicolumn{4}{|c|}{ Gross Domestic Product of Ukraine } \\
\hline & mln UAH & Year over year, \% & mln USA & Year over year, $\%$ \\
\hline 2008 & 948056 & 32,30 & 180239 & 26,10 \\
\hline 2009 & 913345 & $-3,66$ & 117397 & $-34,87$ \\
\hline 2010 & 1082569 & 18,53 & 136516 & 16,29 \\
\hline 2011 & 1316600 & 21,62 & 165402 & 21,16 \\
\hline 2012 & 1408889 & 7,01 & 176332 & 6,61 \\
\hline 2013 & 1454931 & 3,27 & 182094 & 3,27 \\
\hline
\end{tabular}




\begin{tabular}{rrrrr}
\hline 2014 & 1566728 & 7,68 & 131769 & $-27,64$ \\
\hline 2015 & 1979458 & 26,34 & 90635 & $-31,22$ \\
\hline 2016 & 2383182 & 20,40 & 93275 & 2,91 \\
\hline 2017 & 2982920 & 25,17 & 112478 & 20,59 \\
\hline
\end{tabular}

Source: author's calculations based on statistical data of NBU and Minfin of Ukraine.

However, the political situation, war conflict that began in late 2013 led to the continuation of the "era of losses" - thus in 2014 the financial results of most enterprises were negative.

At the same time, agriculture is the only branch in Ukraine, which shows growth over the last 17 years, and the agro-industrial complex provides more than $14 \%$ of Ukraine's GDP. The information displayed in Figure 1 clearly shows that Ukraine is an agrarian country. The agrarian sector brings every third dollar that Ukraine receives. Without these foreign "exchange earnings", it would be difficult to hope for the hryvnia exchange rate stabilization and the NBU's gold and currency reserves increase. Therefore, for Ukraine the agrarian sector is one of the strategic directions of economic development.

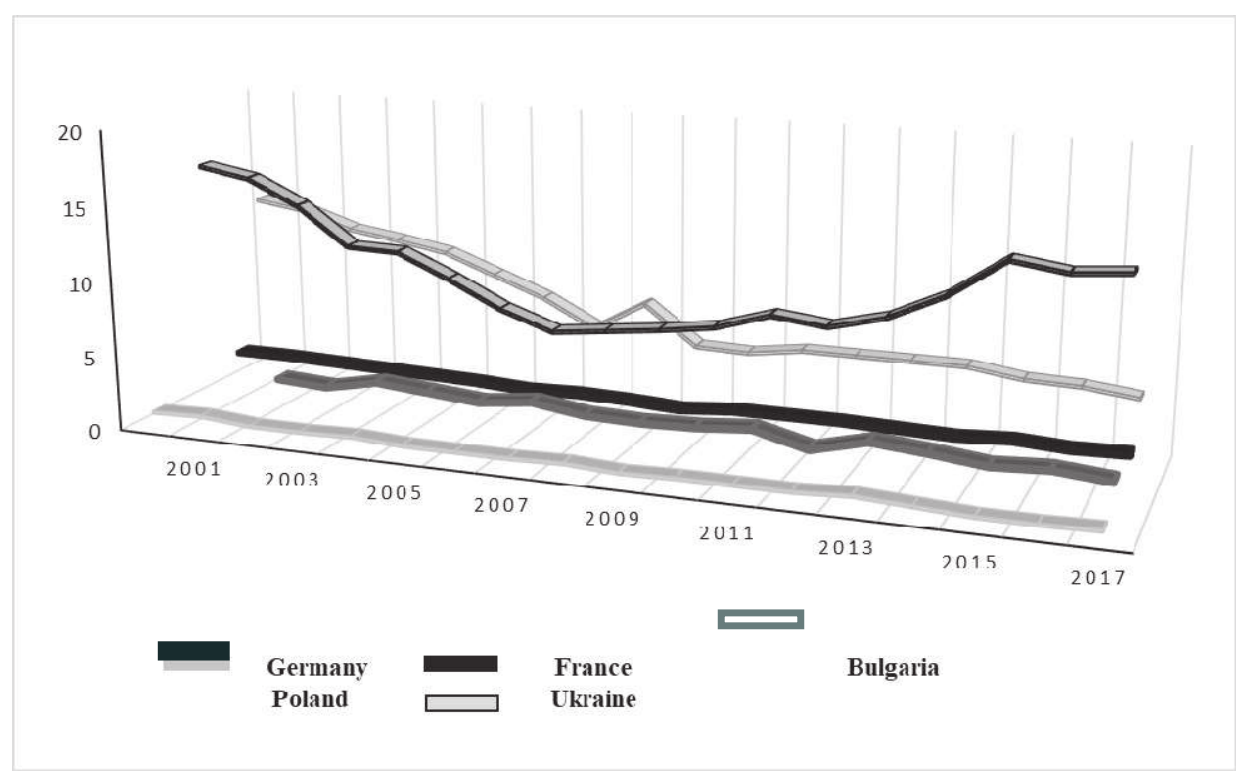

Figure 1. Share of agrarian products in GDP (\%) during 2008-2017

Source: author's calculations based on World Bank Database

On the other hand, the analysis of the current situation in Ukraine is characterized by low efficiency of agrarian production, parceling of agricultural lands as one of the land reform consequences; almost $90 \%$ of the created land plots are leased, a moratorium 
on the sale of agricultural land plots and some other circumstances make it impossible for the land market to develop legally ${ }^{1}$.

Having analyzed the current state of the agrarian sector of Ukraine's economy and having compared some indicators characterizing agriculture to those in the EU countries, one can note the following: the value added in agriculture per one worker in Ukraine is about 3,5 thousand USD, while this indicator in the EU countries is from 5 to 60 thousand USD; the labor productivity in agriculture per one worker in Ukraine compared to the EU is very low too (Fig. 2).

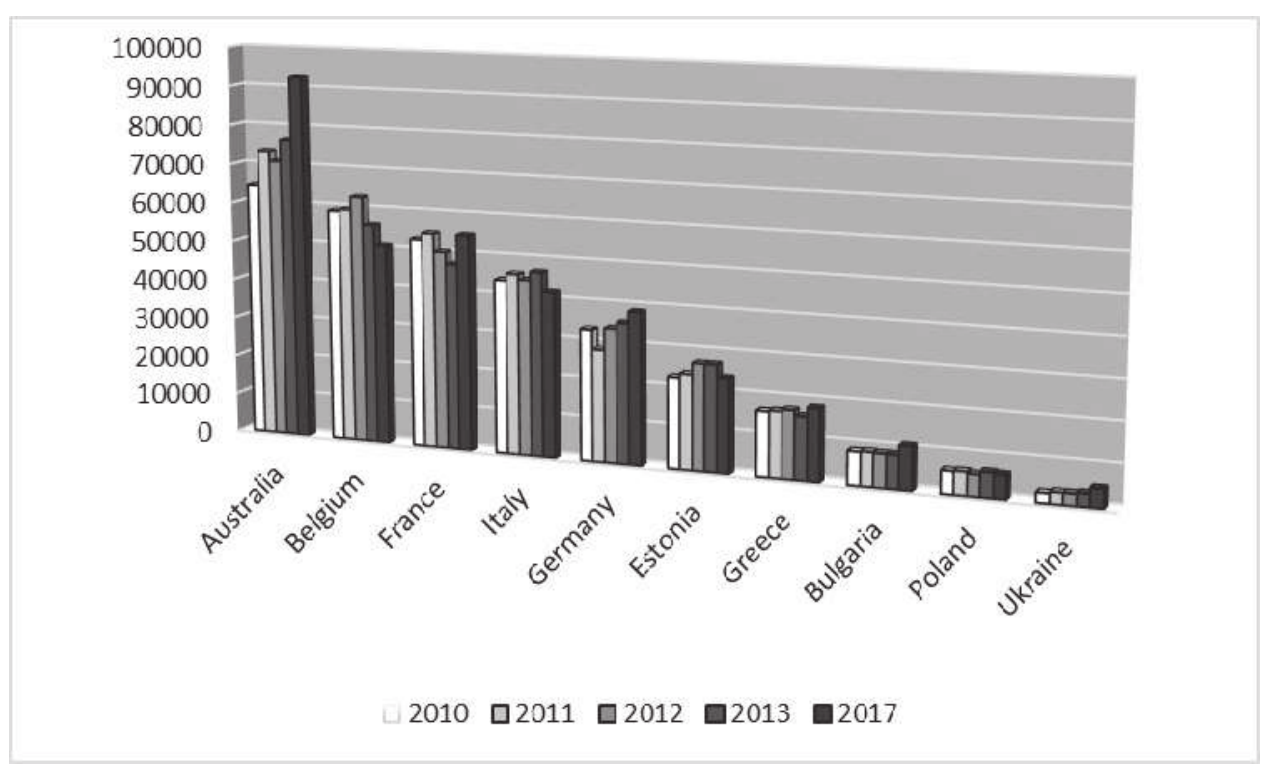

Figure 2. Agriculture value added per worker, US\$ (2010-2013 years - constant 2005 US\$, 2017 year - constant 2010 US\$)

Source: based on FAO's FAOSTAT Database and World Bank.

The main objective of the research is to develop a system of measures aimed at developing land relations, in particular the land market introduction in Ukraine.

Nowadays, the efficient functioning of the land market for Ukraine is not only an important prerequisite for the development of the agrarian sector, but also a necessary one. Economic turnover of agricultural land will contribute to attracting significant financial resources to agricultural production, in addition thereto it will contribute to additional revenue to the state budget.

Economic development is multi-faceted, and it can be argued that in rural areas relatively small-scale agricultural, forestry and fish farming developments are essential to economic development, providing jobs and stimulating the local economy ${ }^{2}$.

\footnotetext{
${ }^{1}$ Kruchok N. Improving of land legislation in Ukraine. Scientific Papers of the NULES, No. 169, 2012.

2 Macmillan, D.: An economic case for land reform. Land Use Policy, № 17, 2000.
} 
The second objective of the research is to determine the economic impact of the effective turnover of land plots.

\section{Literature review}

Engaging land in economic turnover by buying, selling or exchanging land plots, etc. requires effective state regulation of processes connected to this turnover. A. Martyn in his study of the land market formation in Ukraine determined that "The issue of regulation of the land market is one of the most important spheres of the state economic policy. It influences almost all spheres of social and economic life starting from producing of agricultural products to preserving of landscape diversity. At the same time the modern land use in Ukraine has the features of former Soviet extensive methods of management so the agrarian sphere remains a "reservation" for non-market methods of management, legislative restrictions on private property, etc"

The land market is a specific market because land resources should be viewed as assets which have unique features. The peculiarity of the land market was pointed in the studies of M. Szymanska i W. Wielicki. The land market has a specific feature because land is not a good whose quantity could be increased by producing proportionally to demand ${ }^{4}$. Furthermore, an important question which was studied by a number of foreign scientists was an influence of a state policy on functioning of the land market. The results of studying of this questions show that the market of an agricultural land reflects a general macroeconomic situation and structural changes in agriculture. Accessing of Poland to the EU and appearing of different forms of financial support, including direct payments, whose amount depends on a size of a farm, led to an increase of the demand on an agricultural land. The prices of the agricultural land depend on a lot of factors, including demand, location, size of plots and possibility of changing the method of their $u^{5} e^{5}$. It is obvious that the strong relation between a situation of national economy, its development and effective functioning of land market exists that is directly correlated the higher the level of economic and social development of the country the more developed the land market. The study of this relation was presented in works of different scientists, including A. Zaremba who concluded that the market of an agricultural land is a complex category, strongly related to a national economy and its proper functioning enables to rationally manage limited resources as for territories of local communities to a territory of the country. There is an urgent demand for a persistent research with an aim to search for relations and mechanisms of its functioning ${ }^{6}$.

Taking into consideration these facts it should be concluded that, in spite of a significant contribution of researchers from many countries to the theory of science in the sphere of land relations and to the research of different issues concerning a

\footnotetext{
3 Martin A.: Regulation of the land market in Ukraine: monograph. K. Agrar Media Group, 2011

${ }^{4}$ Szymanska M., Wielicki W.: Rynek ziemi rolniczej w Wielkopolsce. Wyd. Akademii Rolniczej w Poznaniu, Poznan, 2005.

5 Kiszczak L., Szczecińska B.: Ceny sprzedaży ziemi rolniczej Skarbu Państwa w województwie zachodniopomorskim [w: Agrobiznes 2005. Zmiany w agrobiznesie po przystapieniu Polski do Unii Europejskiej], T. 1. Pr. Nauk. AE Wroc. 1070, 2005.

${ }^{6}$ Zaremba A.: Analiza rynku ziemi rolniczej Zasobu Własności Rolnej Skarbu Państwa w wybranych powiatach województwa zachodniopomorskiego. Acta Scientiarum Polonorum, Oeconomia, № 3(1), 2004.
} 
development of the land market in practical aspect, there is a number of unsolved questions. This proves the importance of the conducted research.

\section{Result of scientific research}

The analysis of the situation that has developed in the agrarian sector of the Ukrainian economy today enables us to propose a system of economic, institutional and legal measures aimed on successful completion of the land reform in Ukraine, which has been going on for several decades. The implementation of the proposed measures will enable the land market to eventually be introduced and achieve the effective use of land resources ${ }^{7}$.

These include:

1.Creation of favorable economic preconditions for the land market development.

2.Improvement of legal framework for land relations.

3.Abolition of the moratorium on the agricultural land sale with the simultaneous creation and operation of the land institutions such as the Land Mortgage Bank and the Specialized Land Management Agency.

4.Creation of a system of measures of environmental nature.

The above applies primarily to the creation of favorable economic preconditions for the land market development by ensuring sustainable economy development and the national currency stabilization.

The difficult economic situation in the country did affect the financial performance of enterprises. Thus, since 2014, Ukrainian companies report losses. In 2014, the losses amounted to more than 500 million UAH, until 2016 the situation began to gradually improve, but the companies continued to bear losses.

However, the situation is greatly worsened by the fact that over the past 10 years, the Ukrainian economy was characterized by an extremely high level of price growth. Thus, in 2016 the level of inflation reached $143 \%$ (Table 2).

Table 2. Financial results of enterprises taking into account the inflation rate

\begin{tabular}{lrrrrr}
\hline Year & \multicolumn{2}{l}{ Financial result before tax } & $\begin{array}{l}\text { Consumer price index, } \\
\text { (year over year) } \%\end{array}$ & $\begin{array}{l}\text { Accumulated } \\
\text { inflation } \\
(\mathbf{2 0 0 0}=\mathbf{1 0 0}) \mathbf{\%}\end{array}$ \\
\hline 2008 & 8954 & 7 & 122 & 225 \\
\hline 2009 & -42415 & -574 & 112 & 252 \\
\hline 2010 & 58334 & 238 & 109 & 275 \\
\hline 2011 & 122210 & 210 & 105 & 288 \\
\hline 2013 & 101885 & 83 & 100 & 287 \\
\hline 2014 & -523587 & 29 & 101 & 289 \\
\hline 2015 & -340100 & -1888 & 125 & 361 \\
\hline 2016 & -22875 & 65 & 143 & 517 \\
\hline
\end{tabular}

Resource: based on statistical data ${ }^{8}$, Minfin of Ukraine.

\footnotetext{
${ }^{7}$ Kruchok N. Improving of land legislation in Ukraine. Scientific Papers of the NULES, No. 169, 2012.

${ }^{8}$ Statistical Yearbook of Ukraine, 2016. Edited by I. E. Werner. Kiev. State Statistics Service of Ukraine, 2017.
} 
In Fig. 2, an attempt was made to show the level of profitability / loss-making of Ukrainian enterprises given the inflation. Since, it is in this way that one can objectively assess the financial performance of enterprises at such high inflation rate. It should be noted that in 2016, the profitability of enterprises (operating in different sectors of the economy) was $7.4 \%$, however, taking into account inflation, the situation deteriorated considerably - the estimated loss of enterprises was $36 \%$.

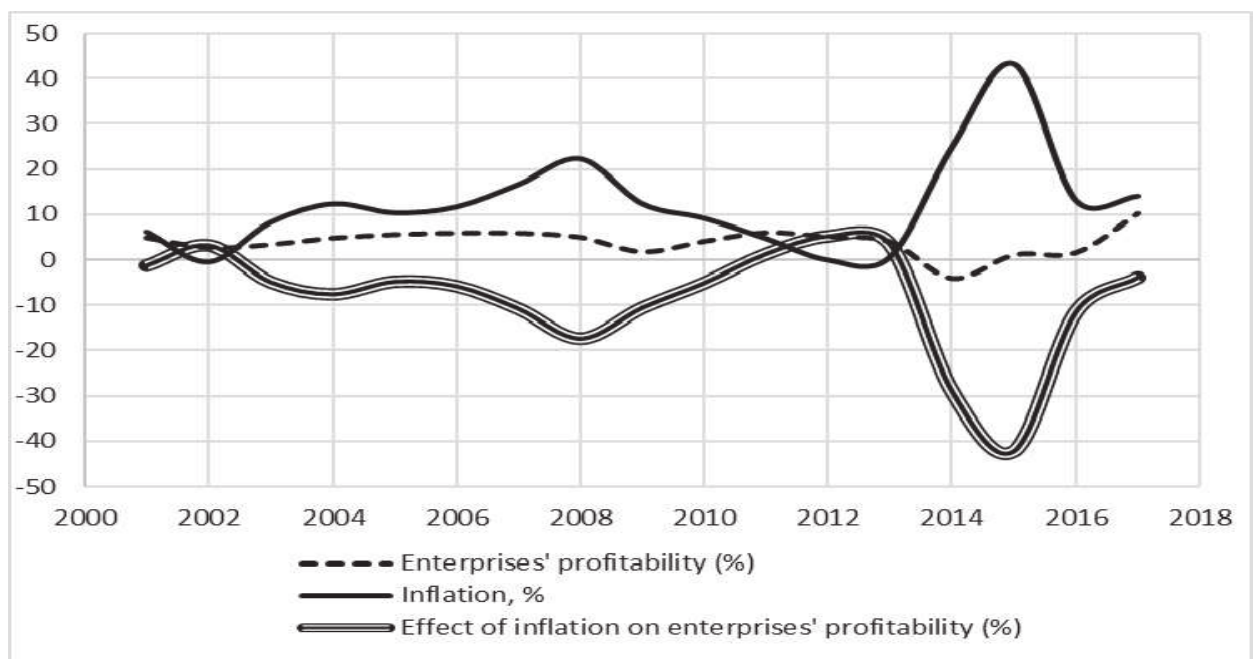

Figure 2. Enterprises profitability and effect of inflation on enterprises profitability (\%), 20012017 years

Source: author's calculations based on statistical data.

Despite the complicated economic situation and the fact that in general the enterprises operate at a loss, the development of the domestic agricultural sector in recent years has been characterized by a significant increase in both the production and the main economic indicators, among which profit occupies a special place. According to the results of 2016, domestic farmers received 90.1 billion UAH of net profit, which is almost $13 \%$ less than the record figure of 2015 (in 2015, net profit was 103.1 billion UAH) ${ }^{9}$.

Table 3. Financial results of agricultural enterprises

\begin{tabular}{crrr}
\hline Year & $\begin{array}{c}\text { Financial result (mln } \\
\text { UAH) }\end{array}$ & $\begin{array}{c}\text { Part of profitable } \\
\text { enterprises (\%) }\end{array}$ & $\begin{array}{c}\text { Part of loss-making } \\
\text { enterprises (\%) }\end{array}$ \\
\hline $\mathbf{2 0 1 0}$ & 17292 & 70 & 30 \\
\hline $\mathbf{2 0 1 1}$ & 25566 & 83 & 17 \\
\hline $\mathbf{2 0 1 2}$ & 26992 & 78 & 22 \\
\hline $\mathbf{2 0 1 3}$ & 15147 & 80 & 20 \\
\hline $\mathbf{2 0 1 4}$ & 21677 & 84 & 16 \\
\hline
\end{tabular}

9 Ukraine in figures. 2017. Statistical Yearbook of Ukraine. Edited by I. E. Werner. Kiev. Publisher LLC "Konsultant", 2018. 


\begin{tabular}{rrrr}
$\mathbf{2 0 1 5}$ & 103138 & 89 & 11 \\
\hline $\mathbf{2 0 1 6}$ & 90661 & 88 & 12 \\
\hline
\end{tabular}

Source: based on statistic data ${ }^{10}$

It should be noted that nowadays the economic efficiency of domestic agrarian production has a clear regional differentiation, which depends on available resources and investment opportunities, as well as on other factors of market influence and influence of other nature. The latter should also include regional specialization, since in agriculture different crops have a relatively uneven profitability of their cultivation (Table 4). An important sector problem is the significant advantage of exported raw materials over the exported finished products.

Table 4. Financial results of agricultural enterprises

\begin{tabular}{|c|c|c|c|c|c|c|c|c|}
\hline \multirow[t]{2}{*}{ Year } & \multicolumn{4}{|c|}{ Agriculture } & \multicolumn{4}{|c|}{ Food production } \\
\hline & 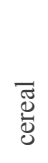 & 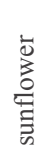 & 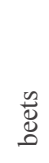 & $\begin{array}{l}\text { d } \\
0 \\
0 \\
\text { J } \\
0 \\
0\end{array}$ & $\stackrel{\bar{J}}{>}$ & 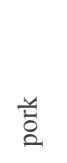 & $\begin{array}{l}\stackrel{\mathscr{J}}{\Xi} \\
\text { I }\end{array}$ & 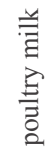 \\
\hline 2008 & 16 & 18 & 7 & 8 & -24 & 0 & -11 & 4 \\
\hline 2009 & 7 & 41 & 37 & 13 & -33 & 12 & -23 & 1 \\
\hline 2010 & 14 & 65 & 17 & 62 & -36 & -8 & -4 & 18 \\
\hline 2011 & 26 & 57 & 37 & 18 & -25 & -4 & -17 & 19 \\
\hline 2012 & 15 & 46 & 16 & -22 & -30 & 2 & -7 & 2 \\
\hline 2013 & 2 & 29 & 3 & 23 & -43 & 0 & -10 & 14 \\
\hline 2014 & 26 & 37 & 18 & 9 & -36 & 6 & -15 & 11 \\
\hline 2015 & 43 & 81 & 28 & 24 & -18 & 13 & $-6,1$ & 13 \\
\hline 2016 & 38 & 63 & 24 & $-3,2$ & -25 & $-4,5$ & 5 & 18 \\
\hline
\end{tabular}

Source: based on statistic data ${ }^{11}$.

In addition to the above, overstated revenues are caused by inflationary processes. As already mentioned, it is necessary to take into account the inflation rate, especially when we talk about agriculture, given the capital turnover. Profits reflected on paper, at a high inflation rate, can actually be a loss.

Another reason for the overstated revenues of agricultural producers is the rent rate. In 2016, the average rent rate was about $\$ 30$ per hectare. In 2017, this indicator increased somewhat but remained low.

Land owners, who are mostly retired, do not have any support from the government; moreover their rights are often violated. In addition to raider attacks that are increasingly taking place in Ukraine, which does not involve any payments for land use, rents are lower than they should be. Thus, agricultural producers overstate their incomes, taking away part of the landowner's income. This issue must be settled and it is impossible without government intervention. According to preliminary calculations,

10,11 Statistical Yearbook of Ukraine, 2016. Edited by I. E. Werner. Kiev. State Statistics Service of Ukraine, 2017. 
after the land market introduction, the rent will increase by more than 2.5 times. And it will be about $\$ 100$ per 1 hectare of arable land.

Another direction without which the land market introduction could have catastrophic consequences for Ukraine is the improvement of legislation regarding agricultural lands valuation in order to improve the quality of normative and expert monetary valuation of such lands, as well as the abolition of the moratorium on the agricultural land sale.

The analysis of the legislation in the field of land valuation has made it possible to draw the following conclusions: the Law of Ukraine "On Land Valuation" contains general provisions on the procedure for boning of soils, and the economic valuation of land plots ${ }^{12}$. The Law does not contain any provision as to how this valuation is made and what factors should be taken into account in addition to references to standards, norms, rules and other regulations. Almost 10 years have elapsed since the analysis, but, unfortunately, the relevant Law has not been amended accordingly ${ }^{13}$. Such a situation makes it possible to carry out corruption actions by persons, who conduct land valuation. The lack of specific requirements permits to make valuation upon request and, depending on the needs the price may be intentionally understated or overstated, despite the adoption of new approaches to the valuation of agricultural land. The objective expert monetary valuation of agricultural land during the land market establishment is particularly important.

Carrying out preliminary valuation of agricultural lands using the capitalized rent income method makes it possible to say that in case of the moratorium abolition, the price of a hectare of arable land would be about 1200 USD / ha in Ukraine on average. With the development of the Ukrainian economy and the land market, the price could grow at least several times.

The abolition of the moratorium on the agricultural land purchase and sale should be accompanied by the simultaneous creation and operation of the land institutions such as the Land Bank and the Specialized Land Management Agency ${ }^{14}$. These institutions should act as instruments for implementing state policy in the field of land relations. Such measures can be attributed to the necessary institutional prerequisites (Fig. 3).

One of the key issues (by far not the only one), which hinders the development of the agro-sector, is the lack of cheap long-term loans. The reasons are known - periodic deep devaluation with the subsequent leap of inflation, cataclysms in the banking system, problems with the protection of the creditors' rights, lack of the land market and, of course, of the specialized agencies.

It should be noted that in 2012 an attempt was made to create a State Land Bank in Ukraine $^{15}$. It was assumed that the financial institution will take care of loans for enterprises in the agrarian sector, as well as the implementation of state programs in this field. However, the attempt was not successful and already in 2014 the resolution of the Cabinet of Ministers of Ukraine "On liquidation of a Public Joint-Stock Company "State

\footnotetext{
12 Law of Ukraine "On Land Valuation" No. 1808-IV dated 17.06.2004.

13 Kruchok N.: Effective land reform in Ukraine. Scientific Papers of the NULES, No. 177, 2012.

${ }^{14}$ Kruchok N. Improving of land legislation in Ukraine. Scientific Papers of the NULES, No. 169, 2012.

15 Law of Ukraine "On Amendments to Certain Legislative Acts of Ukraine on Facilitation of Mortgage Lending" dated 05.07.2012 No. 5059-VI // Official Bulletin of Ukraine, No. 60, p. 48, article 2410, 2012.
} 
Land Bank" was approved. In 2016, the Bank was liquidated due to "insolvency". The real reason for the Bank liquidation was the failure to amend the legislation, which made the Land Bank unable to carry out banking activities provided for in the charter. This again confirms the reluctance of the state to create all the prerequisites for creating a transparent land market.

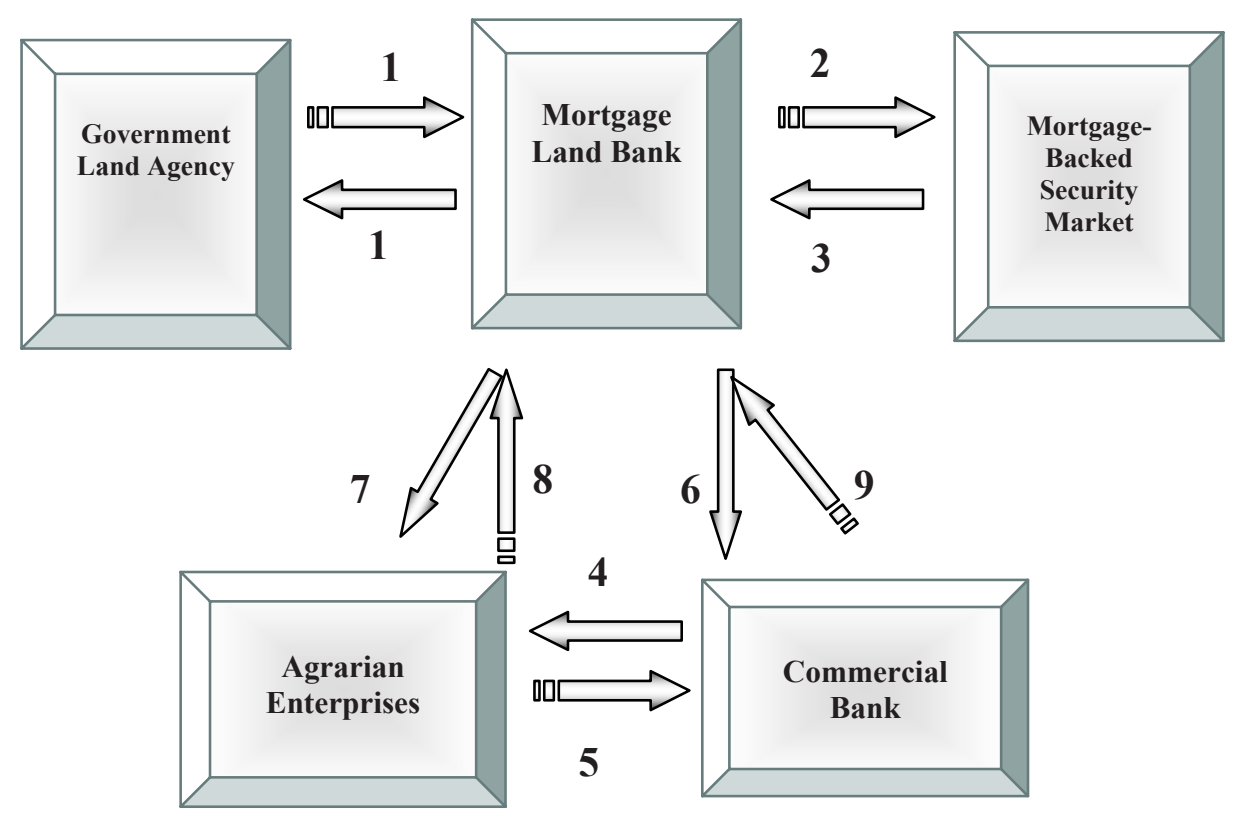

Figure 3. The mechanism of mortgage refinancing by the Mortgage Land Bank through the use of land plots of state ownership:

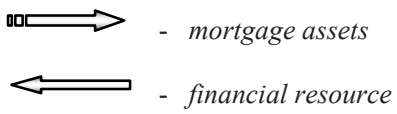

1. Use of land as a security for mortgage securities.

2 . Issue and placement of mortgage securities.

3,6 . Credit resources.

4, 7. Mortgage loans.

5, 8, 9. Mortgage Assets.

10. Release of land plots.

Source: authors' research

For realization of the first steps in the real development of a transparent market of land plots of various purposes, especially agricultural one, it is expedient to establish an institution for the sale of land and title thereto, as well as the purchase of land for public 
purposes - the Government Land Agency. And the main function of the Mortgage Land Bank - would be refinancing through the issue of mortgage bonds.

\section{Conclusions}

1. The analysis of the situation in the agrarian sector of the Ukrainian economy made it possible to propose a system of measures of economic, legal and institutional character, necessary for the creation and efficient functioning of the agricultural land market. Depending on whether the listed measures can be implemented, one can state that Ukraine is waiting for two options: receipt of significant investments in the agrarian sector of the economy and, consequently, its rapid development, or extremely negative consequences and land degradation, provided that Ukraine does not abandon corruption schemes and is not prepared at the appropriate level for such an important event as the land market introduction.

2. After the land market introduction, farmers will have more solid assets for collateral. This applies to both large and small players. The biggest obstacle to access to financing for small and medium-sized agricultural producers is the lack of collateral.

3. The introduction of the land market will provide the agricultural sector of Ukraine with an additional investment resource. After analyzing FAO and World Bank data, it can be argued that the required annual investment in the agro-industrial complex amounts to 4.2-5.2 billion USD.

4. The land market introduction will have the following effects:

- the land will become a commodity and the rights of the landowners will not be violated;

- attracting significant investments to the agrarian sector. According to forecasts, the amount of such investments will be about 5 billion USD by 2025;

- increased investment in agro-industrial complex will cause labor productivity increase due to modernization and agricultural innovation at EU level;

- investments will create new jobs in agriculture. In spite of the automation of many processes, the demand for labor in the production processes of a deeper processing of products will increase causing an increase in the number of specialists;

- the state budget will receive proceeds from land sale and lease transactions. Thus, after the moratorium abolition, the total state budget revenues for the next 8 years can range from 2.5 to 4.3 billion USD.

\section{References}

Deininger, K., Feder, G., Gordillo de Anda, G., \& Munro-Faure, P.: Land policy to facilitate growth and poverty reductions. In Groppo, P. (Ed), Land Reform: Settlement and Cooperatives, FAO, 3 Special Edition, 2003.

Deininger, K. W., \& Binswanger, H.: The evolution of the World Bank's land policy: Principles, experience and future challenges. The World Bank Research Observer, № 14(2), 1999.

Macmillan, D. C.: An economic case for land reform. Land Use Policy, № 17, 2000.

Kiszczak L., Szczecińska B.: Ceny sprzedaży ziemi rolniczej Skarbu Państwa w województwie zachodniopomorskim [w: Agrobiznes 2005. Zmiany w agrobiznesie po przystapieniu Polski do Unii Europejskiej], T. 1. Pr. Nauk. AE Wroc. 1070, 2005.

Kruchok N.: Effective land reform in Ukraine. Scientific Papers of the NULES, No. 177, 2012. 
Kruchok N. Improving of land legislation in Ukraine. Scientific Papers of the NULES, No. 169, 2012 Law of Ukraine "On Land Valuation" No. 1808-IV dated 17.06.2004.

Law of Ukraine "On Amendments to Certain Legislative Acts of Ukraine on Facilitation of Mortgage Lending" dated 05.07.2012 No. 5059-VI // Official Bulletin of Ukraine. No. 60, p. 48, article 2410, 2012.

Martin A.: Regulation of the land market in Ukraine: monograph. K. Agrar Media Group, 2011.

Statistical Yearbook of Ukraine, 2016. Edited by I. E. Werner. Kiev. State Statistics Service of Ukraine, 2017

Szymanska M., Wielicki W.: Rynek ziemi rolniczej w Wielkopolsce. Wyd. Akademii Rolniczej w Poznaniu, Poznan, 2005.

Ukraine in figures. 2017. Statistical Yearbook of Ukraine. Edited by I. E. Werner. Kiev. Publisher LLC "Konsultant", 2018.

World Bank: The World Bank report 2005 . The World Bank, Washington DC, 2005.

Zaremba A.: Analiza rynku ziemi rolniczej Zasobu Własności Rolnej Skarbu Państwa w wybranych powiatach województwa zachodniopomorskiego. Acta Scientiarum Polonorum, Oeconomia, № 3(1), 2004.

Zaremba A.: Czynniki różnicujące ceny ziemi rolniczej w wybranych powiatach województwa zachodniopomorskiego. Folia Univ. Agric. Stetin., Ser. Oeconomica № 252 (46), 2007.

http://www.fao.org

https://worldbank.org

https://bank.gov.ua

\section{Streszczenie}

W opracowaniu omówiono zagadnienia związane $\mathrm{z}$ realizacją reformy rolnej na Ukrainie. Zasadniczą uwagę zwrócono na opracowanie systemu działań, mających na celu rozwój stosunków ziemskich na Ukrainie, w szczególności wprowadzenia rynku ziemi rolnej, a także określenia korzyści ekonomicznych $\mathrm{z}$ tytułu efektywnego obrotu działkami rolnymi. Przeprowadzono analizę sytuacji gospodarczej na Ukrainie w okresie ostatnich 10 lat. Zidentyfikowano zagadnienia związane z przepisami dotyczącymi gruntów, a w szczególności ich wycena. Zaproponowano instytucje, bez których funkcjonowanie rynku ziemi rolnej jest niemożliwe. Przeprowadzona analiza dała podstawę do zaproponowania wstępnych warunków o charakterze ekonomicznym, prawnym i instytucjonalnym, niezbędnych do rozwoju stosunków ziemskich. Zaproponowano również mechanizm refinansowania hipotecznego, poprzez emisję hipotecznych papierów wartościowych.

Słowa kluczowe: warunki ekonomiczne, prawne i instytucjonalne, rynek ziemi, wycena gruntów, ziemski bank hipoteczny, moratorium na sprzedaż ziemi rolnej.

Informacja o autorach:

Dr hab. Natalia Wasilewska, prof. UJK

Jan Kochanowski University in Kielce

Faculty of Social Sciences

Department of Economy and Management

Żeromskiego st. 5

25-369 Kielce

E-mail: nwasilewska@unipt.pl

ORCID: 0000-0001-8638-4735

Prof. dr hab. Tetiana Kaminska, Rector, Kyiv Cooperative Institute of Business and Law Lomonosova st. 18, Kyiv, Ukraine 